\title{
TAG-TEAM TAKEOVER: USURPATION OF WOODPECKER NESTS BY WESTERN BLUEBIRDS
}

\author{
SAMUEL COWELL, KIM SULLIVAN, HANNAH DOMGAARD, SARA \\ LORSCHEIDER, MARIAH PANOUSSI, LINDSEY PARRISH, and TARYN \\ RODMAN, Department of Biology, Utah State University, 5305 Old Main Hill, \\ Logan, Utah 84322-5305; samueldavidcowell@gmail.com \\ TERESA LORENZ, USFS Pacific Northwest Research Station, 3625 93rd Ave. \\ SW, Olympia, Washington 98512 \\ PHIL FISCHER, 22620 U.S. Highway 12, Naches, Washington 98937
}

ABSTRACT: Woodpeckers provide important ecological services by excavating nesting cavities that are used by many forest birds and other animals. Demand for nesting cavities by secondary cavity nesters can lead to intense competition for this limited resource. The Western Bluebird (Sialia mexicana) is known to usurp nests from its own and other species. However, the process by which bluebirds take over nests from woodpeckers larger than themselves has not been well documented. In order to understand this process, we analyzed 112 hours of video footage of nests of a Black-backed (Picoides arcticus) and a Hairy Woodpecker (P. villosus) located in the Okanogan-Wenatchee National Forest in Washington. Usurpation first involves a short period of physical confrontation followed by a prolonged period of constant presence around the nest. The male and female bluebirds cooperate by taking turns harassing the woodpecker and guarding the nest. This may be of concern to managers as the Black-backed Woodpecker is considered a species at risk in certain locations.

In temperate forests, woodpeckers are the primary excavators of nesting cavities that are later used by many species of birds and mammals. The demand for these cavities by secondary cavity users can lead to intense competition (Miller 2010). Because of this, woodpeckers may be prone to having their nests usurped by both other woodpecker species and secondary cavity nesters (Loeb and Hooper 1997, Kronland 2007). The bluebirds are secondary cavity nesters that defend their own nests aggressively and usurp cavities from other birds (Frye and Rogers 2004, Guinan et al. 2008, Gowaty and Plissner 2015), including woodpeckers (Nappi and Drapeau 2009, Kozma and Kroll 2012). However, these events seem rare (only one event was reported in in the latter two studies), and the mechanism by which bluebirds usurp a woodpecker nest has not been well documented.

Here, we describe the process by which Western Bluebirds (Sialia mexicana) usurped active nests from woodpeckers. Our work took place on the east slope of the Cascade Range of Washington. Common primary excavators in this area include the Hairy Woodpecker (Picoides villosus), Black-backed Woodpecker (P. arcticus), White-headed Woodpecker (P. albolarvatus), and Northern Flicker (Colaptes auratus) (Haggard and Gaines 2001). Both the Black-backed and White-headed woodpeckers have been petitioned or listed as endangered, threatened, or species of concern in several states and at the national level (Murphy and Lehnhausen 1998, Bonnot et al. 2008). Common secondary cavity users that may compete for cavities are the Western Bluebird, Mountain Bluebird (Sialia currucoides), and House Wren (Troglodytes aedon) (Haggard and Gaines 2001).

Video cameras recorded active woodpecker nests, and, in reviewing these 
videos, we observed two usurpations by pairs of Western Bluebirds. We then scored the videos to examine the behaviors by which the bluebirds usurped the nests, nest defense by the woodpeckers, and the progress of the takeover.

\section{METHODS}

In 2015 we set up video cameras near woodpecker nests to test techniques for documenting nest failures. Nests were located in burned coniferous forest in the Naches Ranger District, Okanogan-Wenatchee National Forest in Washington state (approximately $46^{\circ} 45^{\prime} \mathrm{N}, 120^{\circ} 58^{\prime} \mathrm{W}$ and $47^{\circ} 30^{\prime}$ $\left.\mathrm{N}, 120^{\circ} 33^{\prime} \mathrm{W}\right)$. The fires had been prescribed by the U.S. Forest Service from 2006 to 2014. Their severities were mixed, creating a mosaic of small patches (0.1-24.2 ha), some burned severely ( 80-90\% canopy mortality), others lightly ( $\sim-10 \%$ canopy mortality), in an otherwise live forest. Forest composition varied by aspect, elevation, and distance from the Cascade crest, but most sites were dominated by a mixture of ponderosa pine (Pinus ponderosa), Douglas fir (Pseudotsuga menziesii), and grand fir (Abies grandis).

In total, we monitored over 40 nests of four species, the Black-backed Woodpecker, White-headed Woodpecker, Hairy Woodpecker, and Northern Flicker. We began monitoring our earliest nest on 28 April 2015 and concluded monitoring our latest on 28 June 2015. In this pilot study, the time over which we monitored each nest varied, from two to seven days per week through the season. We used Panasonic camcorders (model HCV160) with LiPolymer batteries (model 1055275-2C) manufactured by Mogen Industrial Limited. Cameras were mounted on a tree 20-50 m from the nesting cavity. Camera batteries and the 64-gigabyte Secure Digital card were changed out every day.

Of the two woodpecker nests taken over by Western Bluebirds, one (Angel Burn) was an active Black-backed Woodpecker nest. The other (Hause Creek) was originally excavated by Black-backed Woodpeckers, but Hairy Woodpeckers had occupied the cavity by the time filming began. We monitored the Angel Burn nest in the Rattlesnake Creek drainage for six 24-hour periods, on 14 15, 19, 20, 28, and 30 May, the Hause Creek nest in the Tieton River drainage for ten 24-hour periods, 28 April-8 May, skipping 3 May.

Our review of the video recordings began with an initial screening of 2-hour segments in which one of six observers recorded any activity near the woodpecker nest and the time of the occurrence. Observers watched and listened for woodpeckers, Western Bluebirds, rodents, and any other animals that approached the nest. For each animal, the observers recorded the species, sex, behavior, method of detection (visual or auditory), time at which it appeared in the frame, time at which it appeared at the cavity (if applicable), time at which it exited the frame, duration of the event, and if it was alone or interacting with other animals. By these methods, we identified the time from when bluebirds first appeared around the woodpecker nest to when usurpation was complete (defined by woodpeckers not being seen or heard at or around the nesting cavity for at least 24 hours).

Multiple observers then watched all video segments with woodpecker-bluebird interactions a second time and scored them according to an ethogram 
developed for this study and based on behavior described by Brawn (1984), Guinan et al. (2008), and Kronland (2007). Interactions were categorized into two categories (displacement or chasing) with two sub-categories (with or without physical contact). Displacement was defined as one bird leaving a spot because of the presence of another bird. Chasing was defined as one bird continuing to aggressively pursue another bird even after the latter already left its previously occupied spot. Any vocalizations or drumming were also scored. For each event, we defined the actor as the initiator of the interaction and the recipient as the one experiencing the initiator's action. We recorded the distance at which initiation occurred (with respect to the body length of the actor), the closest distance between the birds, the place where the interaction occurred, the outcome of the event, the duration of the event, and the time until the next interaction took place.

\section{RESULTS}

Western Bluebirds successfully drove out the resident woodpeckers at both nests. At the Angel Burn nest, Black-backed Woodpeckers and Western Bluebirds were seen together on or within $1 \mathrm{~m}$ of the nesting cavity intermittently from 14 to 16 May 2015. The Black-backed Woodpeckers were not seen at the nesting cavity after 16 May 2015. At the Hause Creek nest, Black-backed Woodpeckers were photographed excavating a cavity on 18 April 2015. However, in our first video footage of that nest on 28 April 2015, only Hairy Woodpeckers and Western Bluebirds were seen at the nesting cavity. Hairy Woodpeckers were not seen after 30 April 2015.

At the Hause Creek nest, the takeover period lasted about 24 hours. Bluebirds were already present at the Angel Burn nest when we began filming, so the length of the takeover period cannot be strictly defined. We defined the end of the usurpation as the last visit the woodpecker made to the cavity before an absence of at least 24 hours. At the Angel Burn nest, the Black-backed Woodpeckers were heard presumably excavating a new nest about 22 hours after they were last seen at the original nest.

At the Angel Burn nest, nine out of ten bluebird-woodpecker interactions occurred within the first 24 hours, and at the Hause Creek nest, six out of seven of these interactions also occurred within the first 24 hours. The majority of interactions were chases (six of ten at the Angel Burn nest, four of seven at the Hause Creek nest), with the Western Bluebird being the initiator in all cases (Tables 1 and 2). Vocalizations by both bluebirds and woodpeckers accompanied $40 \%$ of all chases. In five of the ten chases, both the male and female bluebird flew directly at the woodpecker from either side with physical contact occurring (see videos at www.westernfieldornithologists. org/tagteamtakeover). We observed no sexual discrimination, as both male and female bluebirds attacked both male and female woodpeckers. Woodpeckers responded with vocalizations and a defensive display with open wings but no direct chases toward the bluebirds. Woodpecker presence at the nest dropped off after the first 6-10 hours. At both nests the woodpeckers returned after 24 hours but were chased by the bluebirds and not seen afterward. All interactions described here took place immediately at or within $1 \mathrm{~m}$ of the nesting cavity. 
Table 1 Numbers of Behaviors Video-Recorded during Takeover of a Nest of the Black-backed Woodpecker (Angel Burn) by Western Bluebirds

\begin{tabular}{|c|c|c|c|c|c|c|}
\hline \multirow[b]{2}{*}{ Date and time } & \multicolumn{2}{|c|}{ Behavior $^{\alpha}$} & \multicolumn{4}{|c|}{ Western Bluebird sex } \\
\hline & Chase & Vocalization & Both $^{b}$ & Male & Female & Unknown \\
\hline \multicolumn{7}{|l|}{14 May } \\
\hline 11:00-13:00 & 2 & 1 & 3 & 0 & 0 & 0 \\
\hline $13: 00-15: 00$ & 1 & 0 & 1 & 0 & 0 & 0 \\
\hline $15: 00-17: 00$ & 0 & 0 & 0 & 0 & 0 & 0 \\
\hline $17: 00-19: 00$ & 0 & 0 & 0 & 0 & 0 & 0 \\
\hline 19:00-21:00 & 0 & 0 & 0 & 0 & 0 & 0 \\
\hline \multicolumn{7}{|l|}{15 May } \\
\hline $5: 30-7: 30$ & 2 & 1 & 2 & 1 & 0 & 0 \\
\hline 7:30-9:30 & 0 & 0 & 0 & 0 & 0 & 0 \\
\hline $9: 30-11: 30$ & 0 & 0 & 0 & 0 & 0 & 0 \\
\hline $11: 30-13: 30$ & 0 & 0 & 0 & 0 & 0 & 0 \\
\hline $13: 30-15: 30$ & 0 & 0 & 0 & 0 & 0 & 0 \\
\hline $15: 30-17: 30$ & 1 & 1 & 0 & 0 & 1 & 1 \\
\hline \multicolumn{7}{|l|}{16 May } \\
\hline $13: 30-15: 30$ & 0 & 0 & 0 & 0 & 0 & 0 \\
\hline $15: 30-17: 30$ & 0 & 0 & 0 & 0 & 0 & 0 \\
\hline $17: 30-19: 30$ & 0 & 0 & 0 & 0 & 0 & 0 \\
\hline 19:30-21:30 & 0 & 0 & 0 & 0 & 0 & 0 \\
\hline \multicolumn{7}{|l|}{17 May } \\
\hline $5: 30-7: 30$ & 0 & 0 & 0 & 0 & 0 & 0 \\
\hline 7:30-9:30 & 0 & 0 & 0 & 0 & 0 & 0 \\
\hline $9: 30-11: 30$ & 0 & 0 & 0 & 0 & 0 & 0 \\
\hline $11: 30-13: 30$ & 0 & 0 & 0 & 0 & 0 & 0 \\
\hline $13: 30-15: 30$ & 0 & 0 & 0 & 0 & & \\
\hline $15: 30-17: 30$ & 0 & 1 & 0 & 1 & 0 & 0 \\
\hline 17:30-19:30 & 0 & 0 & 0 & 0 & 0 & 0 \\
\hline \multicolumn{7}{|l|}{19 May } \\
\hline $11: 30-13: 30$ & 0 & 0 & 0 & 0 & 0 & 0 \\
\hline $13: 30-15: 30$ & 0 & 0 & 0 & 0 & 0 & 0 \\
\hline 20 May: 7:30-9:30 & 0 & 0 & 0 & 0 & 0 & 0 \\
\hline 28 May: $13: 30-15: 30$ & 0 & 0 & 0 & 0 & 0 & 0 \\
\hline Total & 6 & 4 & 6 & 2 & 1 & 1 \\
\hline
\end{tabular}

${ }^{a}$ Includes only actions of the Western Bluebirds directed at woodpeckers, not those of driving off other species from the nest. Vocalizations often accompanied chases and were not always truly separate events.

${ }^{b}$ Both members of the pair acting simultaneously.

\section{DISCUSSION}

We have described how Western Bluebirds engage Black-backed and Hairy woodpeckers in interference competition, keeping the woodpeckers from using their own nest by usurping the nest. The smaller Western Bluebird (23.5-31.5 g; Guinan et al. 2008) uses cooperative, tag-team chases to usurp nests from larger woodpeckers (Black-backed, 67.8-82.7 g, Tremblay et al. 2016; Hairy [northwestern U.S.], about 66-84 g, Jackson et al. 2002). In nest defense against its own species, aggression of the Eastern Bluebird (Sialia sialis) is sex-specific, with females directing aggression to- 
Table 2 Numbers of Behaviors Video-Recorded during Takeover of a Nest of the Hairy Woodpecker (Hause Creek) by Western Bluebirds

\begin{tabular}{|c|c|c|c|c|c|c|}
\hline \multirow[b]{2}{*}{ Date and time } & \multicolumn{2}{|c|}{ Behavior $^{a}$} & \multicolumn{4}{|c|}{ Western Bluebird sex } \\
\hline & Chase & Vocalization & Both $^{b}$ & Male & Female & Unknown \\
\hline \multicolumn{7}{|l|}{$28 \mathrm{Apr}$} \\
\hline $18: 15-20: 15$ & 0 & 0 & 0 & 0 & 0 & 0 \\
\hline $20: 15-22: 15$ & 0 & 0 & 0 & 0 & 0 & 0 \\
\hline \multicolumn{7}{|l|}{$29 \mathrm{Apr}$} \\
\hline $5: 30-7: 30$ & 1 & 0 & 0 & 1 & 0 & 0 \\
\hline $7: 30-9: 30$ & 0 & 0 & 0 & 0 & 0 & 0 \\
\hline $9: 30-11: 30$ & 0 & 0 & 0 & 0 & 0 & 0 \\
\hline $11: 30-13: 30$ & 0 & 0 & 0 & 0 & 0 & 0 \\
\hline $13: 30-15: 30$ & 0 & 0 & 0 & 0 & 0 & 0 \\
\hline $15: 30-17: 30$ & 0 & 0 & 0 & 0 & 0 & 0 \\
\hline $17: 30-19: 30$ & 0 & 0 & 0 & 0 & 0 & 0 \\
\hline 19:30-21:30 & 1 & 1 & 1 & 1 & 0 & 0 \\
\hline \multicolumn{7}{|l|}{$30 \mathrm{Apr}$} \\
\hline $5: 30-7: 30$ & 1 & 2 & 1 & 1 & 1 & 0 \\
\hline $7: 30-9: 30$ & 0 & 0 & 0 & 0 & 0 & 0 \\
\hline $9: 30-11: 30$ & 0 & 0 & 0 & 0 & 0 & 0 \\
\hline $11: 30-1: 30$ & 0 & 0 & 0 & 0 & 0 & 0 \\
\hline $13: 30-15: 30$ & 0 & 0 & 0 & 0 & 0 & 0 \\
\hline $15: 30-17: 30$ & 0 & 0 & 0 & 0 & 0 & 0 \\
\hline $17: 30-19: 30$ & 0 & 0 & 0 & 0 & 0 & 0 \\
\hline 19:30-21:30 & 1 & 0 & 0 & 1 & 0 & 0 \\
\hline \multicolumn{7}{|l|}{4 May } \\
\hline $12: 30-14: 30$ & 0 & 0 & 0 & 0 & 0 & 0 \\
\hline $14: 30-16: 30$ & 0 & 0 & 0 & 0 & 0 & 0 \\
\hline $16: 30-18: 30$ & 0 & 0 & 0 & 0 & 0 & 0 \\
\hline \multicolumn{7}{|l|}{5 May } \\
\hline $16: 00-18: 00$ & 0 & 0 & 0 & 0 & 0 & 0 \\
\hline 18:00-20:00 & 0 & 0 & 0 & 0 & 0 & 0 \\
\hline 7 May: 14:30-16:30 & 0 & 0 & 0 & 0 & 0 & 0 \\
\hline 8 May: $7: 30-9: 30$ & 0 & 0 & 0 & 0 & 0 & 0 \\
\hline Total & 4 & 3 & 2 & 4 & 1 & 0 \\
\hline
\end{tabular}

ancludes only actions of the Western Bluebirds directed at woodpeckers, not those of driving off other species from the nest. Vocalizations often accompanied chases and were not always truly separate events.

${ }^{b}$ Both members of the pair acting simultaneously.

ward females, males toward males (Gowaty and Wagner 1988). In contrast, Western Bluebirds are not known to discriminate by sex when establishing and defending a nesting territory (Herlugson 1980). When another male Western Bluebird showed up at the Angel Burn nest, only the male bluebird of the pair attacked the intruding male, suggesting the female may have been fertile (Dickinson and Leonard 1996). Olsen et al. (2008) reported both members of Western Bluebird pairs defending nests against life-like models of the European Starling (Sturnus vulgaris) by physically attacking the model. Our results suggest that Western Bluebirds usurp nests from woodpeckers in a similar manner. 
Bluebirds disperse cyclically, and individuals dispersing to exploit and colonize new habitat (such as a recently burned forest) have been exposed to higher levels of androgens during development (Duckworth 2008, Duckworth et al. 2015). Nest usurpation may be a function of maternally induced aggression and the limited number of nest cavities available in recently burned forests (White et al. 2005, Duckworth et al. 2015, Edworthy 2016).

In both cases, bluebirds took over the cavity early in the breeding season soon after the woodpeckers had finished excavating and before they had laid eggs (Hause Creek nest, 28 April 2015; Angel Burn nest, 16 May 2015). Early in the breeding season, it may be more efficient for woodpeckers to abandon a nest and excavate a new cavity rather than fight off highly aggressive bluebirds. Later in the breeding season, we observed a male Western Bluebird investigating an active Northern Flicker nest, but there were no physical altercations. At a certain point, nestling woodpeckers may be too large for bluebirds to usurp the nest, and parent woodpeckers may defend the nest more intensely as the time available for reproduction decreases later in the season (Biermann and Robertson 1981).

Usurpation of woodpecker nests by bluebirds may be relevant to management, as the Black-backed Woodpecker is a species of conservation concern in several states, including Washington (Murphy and Lehnhausen 1998, Bonnot et al. 2008). Of the six Black-backed Woodpecker nests we filmed during our pilot study, two were usurped. While we were unable to confirm whether the Hairy Woodpeckers actually usurped the Hause Creek cavity from the Black-backed Woodpeckers that excavated it, this ratio still suggests that there is competition for nest cavities and snags suitable for nesting. However, nesting Western Bluebirds may benefit woodpeckers if enough cavities are available. In our study, the male bluebird was seen chasing off other male bluebirds, and both the male and female bluebird were seen chasing Brown Creepers (Certhia americana) from the nesting tree. Additionally, we saw a male Western Bluebird flying at a Douglas Squirrel (Tamiasciurus douglasii) at an abandoned White-headed Woodpecker cavity. If nest cavities are abundant, bluebirds may inadvertently defend active woodpecker nests from other aggressive secondary cavity nesters and nest predators.

Because of its capacity for aggressiveness, the Western Bluebird is able to usurp cavities from Black-backed and Hairy Woodpeckers quickly when nest sites are limited. Therefore, the key to helping threatened woodpeckers such as the Black-backed is to manage fire regimes within forests so that there is an ample supply of snags available to supply nesting cavities for the woodpeckers, bluebirds, and the other species that depend on them for survival.

\section{ACKNOWLEDGMENTS}

This research was funded by a joint venture agreement between the U.S. Forest Service and Utah State University, agreement 15-JV-11261992-059. All aspects involving wildlife followed guidelines of the university's institutional animal care and use committee, approval number 2590. 


\section{TAG-TEAM TAKEOVER: USURPATION OF WOODPECKER NESTS}

\section{LITERATURE CITED}

Biermann, G. C., and Robertson, R. J. 1981. An increase in parental investment during the breeding season. Anim. Behav. 29:487-489; doi 10.1016/S00033472(81)80109-1.

Bonnot, T. W., Rumble, M. A., and Millspaugh, J. J. 2008. Nest success of Blackbacked Woodpeckers in forests with mountain pine beetle outbreaks in the Black Hills, South Dakota. Condor 110:450-457; doi 10.1525/cond.2008.8460.

Brawn, J. D. 1984. Defense of nest boxes by Western Bluebirds during the postbreeding period. Condor 86:494-495; doi 10.2307/1366842.

Dickinson, J. L., and Leonard, M. L. 1996. Mate attendance and copulatory behaviour in Western Bluebirds: Evidence of mate guarding. Anim. Behav. 52:981-992; doi 10.1006/anbe.1996.0246.

Duckworth, R. A. 2008. Adaptive dispersal strategies and the dynamics of a range expansion. Am. Nat. 172:S4-S17; doi 10.1086/588289.

Duckworth, R. A., Belloni, V., and Anderson, S. R. 2015. Cycles of species replacement emerge from locally induced maternal effects on offspring behavior in a passerine bird. Science 347:875-877; doi 10.1126/science.1260154.

Edworthy, A. B. 2016. Competition and aggression for nest cavities between Striated Pardalotes and endangered Forty-spotted Pardalotes. Condor 118:1-11; 10.1650/condor-15-87.1.

Frye, G. G., and Rogers, K. K. 2004. Probable cavity usurpation via interspecific killing by the Mountain Bluebird (Sialia currucoides). Northwest. Nat. 85:126-128; doi 10.1898/1051-1733(2005)085[0126:PCUVIK]2.0.CO;2.

Gowaty, P. A., and Plissner, J. H. 2015. Eastern Bluebird (Sialia sialis), in The Birds of North America Online (P. G. Rodewald, ed.), no. 381. Cornell Lab Ornithol., Ithaca, NY; doi 10.2173/bna.381.

Gowaty, P. A., and Wagner, S. J. 1988. Breeding season aggression of female and male Eastern Bluebirds (Sialia sialis) to models of potential conspecific and interspecific egg dumpers. Ethology 78:238-250; doi 10.1111/j.1439-0310.1988. tb00234.x.

Guinan, J. A., Gowaty, P. A., and Eltzroth, E. K. 2008. Western Bluebird (Sialia mexicana), in The Birds of North America Online (P. G. Rodewald, ed.), no. 510. Cornell Lab Ornithol.. Ithaca, NY; doi 10.2173/bna.510.

Haggard, M., and Gaines, W. L. 2001. Effects of stand replacement fire and salvage logging on a cavity-nesting bird community in eastern Cascades, Washington. Northwest Sci. 75:387-396.

Herlugson, C. J. 1980. Biology of sympatric populations of Western and Mountain bluebirds. Ph.D. thesis, Washington State University, Pullman.

Jackson, J. A., Ouellet, H. R., and Jackson, B. J. 2002. Hairy Woodpecker (Picoides villosus), in the The Birds of North America Online (A. Poole and F. Gill, eds.), no. 702. Birds N. Am., Philadelphia; doi 10.2173/bna.702.

Kozma, J. M., and Kroll, A. J. 2012. Woodpecker nest survival in burned and unburned managed ponderosa pine forests of the northwestern United States. Condor 114:173-184; doi 10.1525/cond.2012.110034.

Kronland, W. 2007. Nest usurpation by Red-headed Woodpeckers in southeastern Montana. Wilson J. Ornithol. 119:486-489; doi 10.1676/05-139.1.

Loeb, S. C., and Hooper, R. G. 1997. An experimental test of interspecific competition for Red-cockaded Woodpecker cavities. J. Wildlife Mgmt. 61:1268-1280; doi $10.2307 / 3802126$.

Miller, K. E. 2010. Nest-site limitation of secondary cavity-nesting birds in even-age southern pine forests. Wilson J. Ornithol. 122:126-134; doi 10.1676/07-130.1.

Murphy, E. C., and Lehnhausen, W. A. 1998. Density and foraging ecology of wood- 
peckers following a stand-replacement fire. J. Wildlife Mgmt. 62:1359-1372; doi $10.2307 / 3802002$.

Nappi, A., and Drapeau, P. 2009. Reproductive success of the Black-backed Woodpecker (Picoides arcticus) in burned boreal forests: Are burns source habitats? Biol. Cons. 142:1381-1391; doi 10.1016/j.biocon.2009.01.022.

Olsen, R. G., Purcell, K. L., and Grubbs, D. 2008. Nest defense behaviors of native cavity nesting birds to European Starlings, in Proceedings of the Sixth Symposium on Oak Woodlands: Today's Challenges Tomorrow's Opportunities (A. Merenlender, D. D. McCreary, and K. L. Purcell, eds.), pp. 457-470. USDA Gen. Tech. Rep. PSW-GTR-217.

Tremblay, J. A., Dixon, R. D., Saab, V. A., Pyle, P., and Patten, M. A. 2016. Blackbacked Woodpecker (Picoides arcticus), in The Birds of North America Online (P. G. Rodewald, ed.), no. 509. Cornell Lab Ornithol., Ithaca, NY; doi 10.2173/ bna.509.

White, T. H. Jr., Abreu-González, W., Toledo-González, M., and Torres-Báez, P. 2005. Artificial nest cavities for Amazona parrots. Wildlife Soc. Bull. 33:756-760; doi 10.2193/0091-7648(2005)33[756:FTFANC]2.0.CO;2.

Accepted 23 April 2017

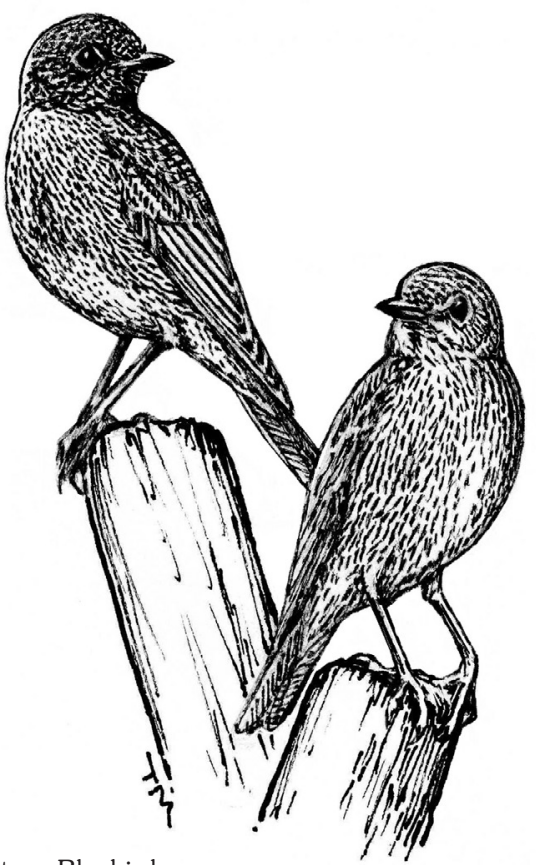

Western Bluebirds

Sketch by Tim Manolis 